OmniAkuatika, 12 (1): 1-12, 2016
ISSN: 1858-3873 print / 2476-9347 online
Mini Review

\title{
Vibriosis in aquaculture
}

\section{Romi Novriadi ${ }^{1, *}$}

${ }^{1}$ Batam Mariculture Development Center, Directorate General of Aquaculture, Ministry of Marine Affairs and Fisheries, Republic of Indonesia PO BOX 60 Sekupang, Batam - 29422

*Corresponding author: romi_bbl@yahoo.co.id

\section{A B S TRACT}

Current growth in aquaculture production is parallel with the increasing number of diseases outbreaks and can affect the production, profitability and sustainability of the industry worldwide. Among the groups of pathogenic microorganisms, vibriosis is the well-known cause of severe economic losses and responsible for (massive) mortality of cultured shrimp, fish and shellfish. Antibiotics and chemicals have been applied in farms for traditional treatment and prevention of Vibriosis. However, the frequent use of chemotherapeutic agents has allowed for the development of drug-resistant strainsand has led to allergy and toxicity in humans. Therefore, the use of prophylactic approaches to stimulate and enhance the immune responses becomes urgent. In this short review, the application of immunostimulant, vaccine, probiotics and quorum quenching molecules to inhibit the communication of Vibrio spp were presented.

Key words: Vibriosis, Aquaculture, Antibiotics, Prophylactic, Virulence, Immune response

\section{INTRODUCTION}

The importance of aquatic farming referred to as "Aquaculture" has been increasing recently as a consequence from the decline production in capture fishery. A closer look at the statistics shows that global aquaculture production continues to grow at an average rate of 8.6 percent per year and attained up to 90.4 million tonnes in 2012 (FAO,2014). In addition, aquaculture plays an important role in the economic development, with estimated farm sales of over US $\$ 144.4$ billion, and provide numerous jobs in the secondary sector, such as fish processing, fish feed industry, trade and marketing, as well as in many ancillary services (FAO, 2014). However, due to the (super) intensification in aquaculture activities, outbreaks of diseases, especially caused by bacterial infection, are being increasingly reported as a significant challenge to the expansion of aquaculture production and affects the economic development of some countries. The annual economic losses associated with diseases worldwide are estimated to be in excess of US $\$ 9$ billion per year (Ruwandeepika, 2010) and caused losses of over US $\$ 120$ million in China during 1990 and 1992 (Wei, 2002).

Meyer (1991) pointed out that bacterial pathogens probably caused more disease problems in aquaculture. Among the many infectious diseases caused by bacteria, vibriosis is classically considered to be the well-known cause of severe losses associated with their invasion to fishes (Austin and Austin, 2007). This disease has been described as vibriosis or bacterial disease, penaeid bacterial septicemia, penaeid vibriosis, luminescent vibriosis or red leg disease (Aguirre-Guzman et al., 2004). The first report of Vibrio disease occurring in an aquaculture system was described by Rucker et al. (1954) without any proper discussion related to the symptoms of the disease among Oncorhynchus gorbuscha, Oncorhynchus keta, and Oncorhynchus taschawytscha along the Washington coast. Today, members of the genus Vibrio have gained attention because several species are associated with human diseases (Amaro and Biosca, 1996) and cause multibillion dollar losses and severe mortality of livestock in many countries, especially in shrimp aquaculture industries (Prayitno and Latchford, 1995; Lightner, 1996; Defoirdt et al., 2007). In addition, 
based on the laboratory-based experiments, pathogens belonging to the Vibrio $\mathrm{sp}$ were pathogenic not only to salt water fish but also to brackish water fish with mortalities up to $100 \%$ (Austin and Austin, 2007) and their prevalence has been increased in the last 44 years, especially in the coastal North Sea (Le Roux et al., 2015). Therefore, in the present study a detailed review including description of pathogen, socio-economic impacts, epidemiology, virulence factors, and control measures was undertaken to study the diseases caused by Vibrio spp. In this short review, several prophylactic approaches used to improve the growth performance, survival and enhance the immune system of aquatic organisms against Vibrio infection within the aquaculture system were also presented.

\section{Vibriosis in aquaculture}

Vibriosis is a potentially serious illness caused by a group of bacteria called Vibrio (Chen et al., 2000). Vibrios are gram negative that are ubiquitous in marine environment and estuarine ecosystems (Austin and Austin, 2007) and can be found free-living in the water column, as part of biofilm, or in association with a host (Thompson et al., 2004). The number of reported Vibrio species has increased rapidly and ten of them have been associated with diseases in human since they can cause skin infections and gastrointestinal disorders (Venkateswaran et al., 1998; Andrews, 2004). Surprisingly, even Vibrio have been reported as one of the causal agents of diseases in aquatic organisms, other species such as Vibrio alginolyticus have been used as probiotics for shrimp production (Vandenberghe, 2003). In general, signs of disease caused by Vibrio include lethargy, tissue and appendage necrosis, slow growth, slow metamorphosis,
Novriadi, 2016, Vibriosis in aquaculture

body malformation, bioluminescence, muscle opacity and melanization (Aguirre-Guzman et al., 2004). Moreover, infected fish show skin discoloration, the presence of red necrotic lesion in the abdominal muscle, and erythema (bloody blotches) at the base of the fins, around the vent, and within the mouth (Anderson and Conroy, 1970). Vibrios could frequently found in mussels and cause irregular circular movements and deterioration of the mussel larvae perna canaliculus soft tissue (Kesarcodi-Watson et al., 2009). In many cases, Vibrios may be classified as an opportunist, only causing disease when the host organisms is immune suppressed or stress due to the (super)intensive culture and adverse environmental conditions (Alderman and Hastings, 1998).

From the description of Ishimaru et al., (1996), Vibrio may be isolated on marine agar with incubation at $25^{\circ} \mathrm{C}$ for $2-7$ days. Moreover, thiosulphate-citrate-bile salt sucrose agar may also be used for selective isolation of Vibrio strains by transferred a loopful of the enrichment culture and incubated at $37^{\circ} \mathrm{C}$ for 18 - 24 hours. Pure colonies were randomly selected and then transferred to tryptic soy agar (TSA, Difco, Spain) supplemented with $1 \% \mathrm{NaCl}$ (Hara-Kudo et al., 2001). Isolates of the Vibrio can be stored in $30 \%$ glycerol at $-80^{\circ} \mathrm{C}$ for further analysis (Khouadja et al., 2013). The observation of colony morphology can be carried out on Zobell $2116 \mathrm{E}$ agar medium (Isnansetyo et al., 2009), while morphological, biochemical and physiological test can be carried out based on the protocol described by Smibert and Krieg (1994). The interest in Vibrios as the scourge of marine fish and shellfish has resulted in the description of new species and a better understanding of the biology of long-recognised taxa (Austin and Austin, 2007).
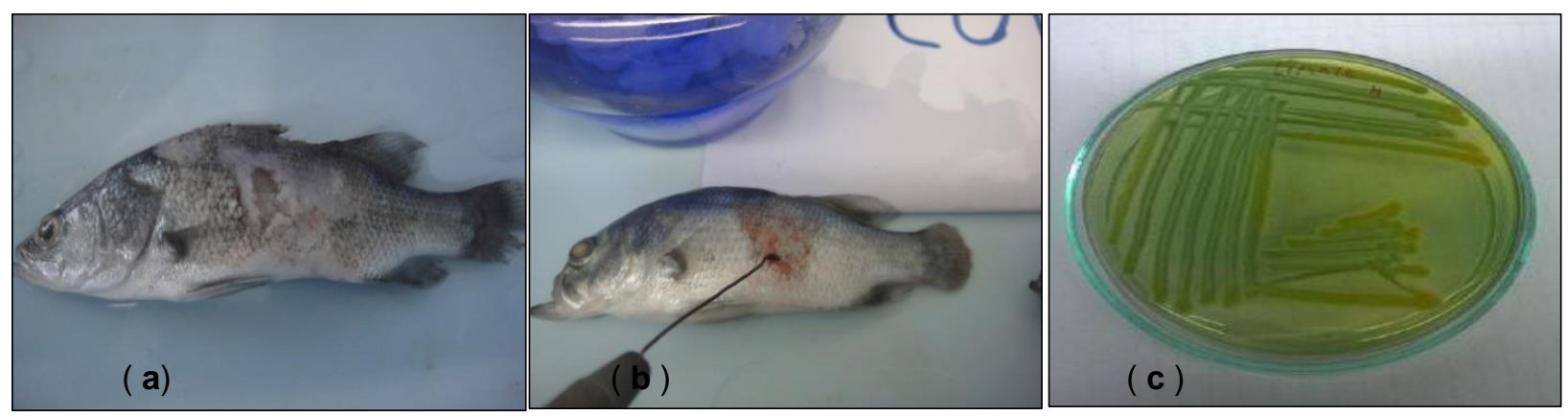

Figure 1. a) lethargy, tissue and appendage necrosis in Asian Seabass Lates calcarifer infected by Vibrio parahaemolyticus and Vibrio damsella; b) Vibrio isolation; and c) green colonies of Vibrio spp in 
3 Omni-Akuatika Vol. 12 No. 1 Mei 2016 : 1 - 12

thiosulphate-citrate-bile salt sucrose agar prior transferred to tryptic soy agar (Courtesy: Romi Novriadi, 2014).

Vibrio abound in the warm $\left(>15^{\circ} \mathrm{C}\right)$ saline aquatic environments (Le Roux et al., 2015), and therefore present a constant threat for any susceptible host, especially for the most important fish species used in marine and brackish water farming. However, evidence is also accumulating that vibriosis may occur in the fresh water environment (Muroga, 1975; Ghittino and Andruetto, 1977). Warming of marine and saline inland waters is also have an important role in support the growth of Vibrio populations and become a major limiting factor in the successful of aquaculture industry (Mahnken, 1975). Vibriosis appears to have been confined initially in European waters (Austin and Austin 2007). A further continuous plankton recorder (CPR) survey in northern Europe showed that the genus Vibrio, including the human pathogen $V$. cholerae, has increased in prevalence in the last 44 years (Vezzulli et al., 2012). Moreover, an authorative publication in Austin and Austin (2007) reported that Vibriosis occurs in more than 14 countries and represents a significant cumulative loss among 48 species of marine fish. Recent study from Soto-Rodriguez et al., (2015) confirmed that, from field and experimental results, Vibrio parahaemolyticus acts as a primary pathogen that causes acute hepatopancreatic necrosis disease (AHPND) for shrimp in Mexico. In addition, six isolates $(\mathrm{H} 1$ to H6) obtained from a shrimp hatchery in Rio Grande do Norte (Natal-Area, Brazil), which had been confronted with disease outbreaks in 2009, were identified to belong to the Harveyi clade of vibrios (Vanmaele et al., 2015). This results suggest that vibriosis is an extremely widespread problem.

\section{Virulence factors and pathology}

The highlight of several studies suggest that Vibrio may considered as a highly virulent fish pathogen with three major infectious cycle, namely: (i) entry of pathogen; (ii) establishment and multiplication, thereby avoiding host defenses and causing damage to host tissues and cells; and (iii) exit (Donnenberg, 2000; Austin and Austin, 2007). These different steps allow the pathogens to infect and damage the host, including products involved in motility, adhesion, host tissue degradation, iron acquisition and protection from host defence (Donnenberg, 2000). One virulence factor that have been identified is a very efficient iron-sequestering system, encoded by the 65-kilobase pair (kb) pJM1 plasmid isolated from prototype O1 strain V. anguillarum (Crosa et al., 1977). The role of this iron-uptake system, consist with siderophore, named anguibactin, and a membrane-receptor complex, in virulence was further confirmed by the introduction of recombinant clones possessing the pJM1-encoded iron-uptake genetics determinants into avirulent $V$. anguillarum strains (Woo and Bruno, 2011).

Another factors that is believed to play a central role in the infectivity of bacterial pathogens, include (i) Haemagglutinating activity affected the intestinal tract and the vascular system of injected animals, (ii) leucocytolytic factor, induced by the presence of $V$. ordalii (Harbell et al., 1979), (iii) the ability to resist the bactericidal effect of non-immune serum (Trust et al., 1981), (iv) the secretion of extracellular cytotoxic and cytolytic factors (Amaro et al., 1994), an elastolytic protease (Kothary and Kreger, 1987), and the availability of iron (Amaro et al., 1994). Clinical and environmental isolates suggest that the virulence expression critically depend on biotic interactions with the host and other resident microbiota. Recently, Vibrio disease cannot be seen as an isolated event but needs to be considered in the context of the microbiome, which includes other non-virulent Vibrio (Le Roux et al., 2015).

The infection process of Vibrio remains unclear, but undoubtedly involves colonization of (attachment to) the host starting with the skin (Spanggaard et al., 2000), and thence penetration of the tissues (Austin and Austin, 2007). Therefore, for the invasion of the host, chemotactic motility is necessary for virulence (Larsen et al., 2004). Moreover, it has been reported as well that bacteriophages are important elements of Vibrio spp in transferring virulence (Pasharawipas et al., 2005). Bacteriophages have been known to confer virulence to bacteria upon infection, a process known as lysogenic conversion (Boyd et al., 2001) whereby a non-pathogenic strain can transform into a virulent strain or a strain with increased virulence. The bacteriophage-encoded proteins provide mechanisms to invade host tissues, avoid host immune defenses and 
damage host cells (Boyd et al., 2001). Another group of vibriosis virulence factors include lytic enzymes, which are produced by many pathogenic bacteria and often play a central role in pathogenesis (Finlay and Falkow, 1997). These enzymes that consist with hemolysins, proteases (including caseinase and gelatinase), able to cause damage to host tissues, thereby allowing the pathogen to obtain nutrients and to spread through tissues (Defoirdt et al., 2007).

\section{Epidemiology of Vibrio infections in aquaculture}

In general, most cases of vibrio infections evidence that has been provided showing that Vibrio species are natural inhabitants of marine aquatic environment in both temperate and tropical regions. However, recent evidence is also accumulating that vibriosis may occur in freshwater condition (Muroga, 1975) and in the inland areas far from any sea cost (Rhodes et al., 1985). Contact with contaminated water and also consume raw, poorly cooked, or decontaminated shellfish are at risk for vibrio infections (Janda et al., 1988). In addition, Vibrio spp have been isolated from a variety of environment samples including water, sediment, plankton, shellfish, fin fish and crustaceans (Dalsgaard, 1998). According to Chatterjee and Haldar (2012), Major Vibrio spp. associated with shrimp diseases include $V$. harveyi, $V$. parahaemolyticus, $\quad V$. alginolyticus, $V$. anguillarum, $V$. vulnificus, and $V$. splendidus. Meanwhile, $V$. anguillarum, $V$. salmonicida, and $V$. vulnificus are among the main bacterial pathogens in several fish species (Austin and Austin, 2007).

Vibriosis had gained considerable notoriety in aquaculture, where it has become major limiting factor and widely responsible for mortality in cultured aquaculture systems worldwide. An authoritative publication reported that vibriosis occurs in more than 14 countries, where it has ravaged approximately 48 species of marine fish (Austin and Austin, 2007). To cite one example, in Denmark, vibriosis has resulted in cumulative losses of $30 \%$ among eel populations (Austin and Austin, 2007). Significant economic losses and other impacts due to the vibriosis in aquaculture system are presented in Table 1. Until around 1980, Vibrio anguillarum was the only Vibrio species connected with disease in fish (Egidius, 1987). However, during the last few years, several new fish pathogens belonging to this genus have
Novriadi, 2016, Vibriosis in aquaculture

been described, including the new Characterization of 6 Vibrio strains $(\mathrm{H} 1-6)$ isolate from a shrimp hatchery in Rio Grande do Norte (Natal-Area, Brazil), where high mortalities were faced at that moment (Vanmaele et al.,2015). Moreover, the $69 \mathrm{~kb}$ plasmid pVPA3-1 found in Vibrio parahaemolyticus become the causative agent of acute hepatopancreatic necrosis diseases (AHPND) and responsible for mass mortalities in farmed penaeid shrimp (Han et al., 2015). This disease that also referred to as early mortality syndrome has seriously impacted the shrimp aquaculture industry in both Asia and Central America (Mexico) (Flegel, 2012; SotoRodriguez et al., 2015) and cause economic losses for more than US\$ 1 billion (Zorriehzahra and Banaederakhshan, 2015).

\section{Control of Vibriosis in Aquaculture}

To control the vibriosis in aquaculture, feeding infected fish with antibiotic-medicated food (Pridgeon et al., 2012) and the application of antibiotics via the oral route to groups of fish that share tanks or cages are common practices (Defoirdt et al., 2007).However, these approaches may be ineffective mainly due to the development of resistance to antimicrobial compounds in pathogen caused by the frequent use of antimicrobial compounds.Another problem created by unrestricted use of antibiotics is the presence of residual antibiotics in commercialized of aquaculture products and has led to allergy and toxicity in humans (Cabello, 2004). The massive use of antibiotics for livestock's may result in frequent rejections from destination exports countries due to the presence of residues from the use of prohibited antibiotics. Recently, data collected by EU, United States, Australian and Japanese authorities showed that 2,400 export consignment of Vietnamese fishery products have been rejected by Unites States authority (during 2002 - 2010), 422 shipments have been rejected by EU authorities, while Japanese and Australian authorities have refused market entry to 464 and 206 Vietnamese shipments $(2003$ - 2010), respectively (IDEJETRO, 2014). In view of the above circumstances, the use of antibiotics not only caused severe decline in production but also loss of competitiveness in export market.

The antibiotics resistance is common in bacteria isolated from the aquaculture system. Study from Akinbowale et al., (2006) showed that $74 \%$ of Vibrio spp isolated from aquaculture settings in different states in Australia were found to be resistant to at least one antibiotic. 
5 Omni-Akuatika Vol. 12 No. 1 Mei 2016 : 1 - 12

Resistance to Ampicillin, Amoxicillin, Cephalexin,

Cephalothin, Gentamycin, Erythromycin,

Tetracycline, and Oxytetracycline was found in

several isolates during the sampling campaign program.

Table 1.

Examples of socio-economic and other impacts of Vibrio related diseases in aquaculture system.

\begin{tabular}{|c|c|c|c|}
\hline Country & $\begin{array}{l}\text { Vibrio spp. caused } \\
\text { disease }\end{array}$ & Losses and other impacts & Reference \\
\hline China & V. fluvialis & $\begin{array}{l}>\text { US } \$ 120 \mathrm{M} \text { annual losses between } \\
1990-1992\end{array}$ & Wei (2002) \\
\hline Egypt & $\begin{array}{l}V . \text { anguillarum } \\
V . \text { alginolyticus } \\
\text { V. ordalii } \\
\text { V. harveyi }\end{array}$ & $\begin{array}{l}\text { Red spot on the ventral and lateral area } \\
\text { Swollen and dark skin lesions, necrosis, } \\
\text { hemorrhagic areas, exophthalmia and } \\
\text { ulcers on the skin surface } 50 \% \text { mortality } \\
\text { in Seabass and Seabream }\end{array}$ & $\begin{array}{l}\text { Saad and Atallah } \\
\text { (2014) }\end{array}$ \\
\hline Indonesia & Luminescent Vibrio & $\begin{array}{l}>\text { US } \$ 100 \mathrm{M} \text { in } 1991 \text { at shrimp } \\
\text { hatcheries }\end{array}$ & APEC (2000) \\
\hline Tunisia & V. parahaemolyticus & $\begin{array}{l}\text { Darkened body color, white nodular skin } \\
\text { lesion, and sudden death with } \\
\text { haemorrhages in the skeletal muscle of } \\
\text { European Seabass }\end{array}$ & $\begin{array}{l}\text { Khouadja et al. } \\
\text { (2013) }\end{array}$ \\
\hline Mexico & V. parahaemolyticus & $\begin{array}{l}\text { Acute Hepatopancreatic Necrosis } \\
\text { Disease (AHPND) in L. vannamei } \\
\text { include empty gut, anorexia, lethargy, } \\
\text { expanded chromatophores and pale HP } \\
\text { with discoloration }\end{array}$ & $\begin{array}{l}\text { Soto-rodriquez et } \\
\text { al. (2015) }\end{array}$ \\
\hline Thailand & V. harveyi & Mass mortalities in P. monodon & $\begin{array}{l}\text { Groumellec et al. } \\
\text { (1995) }\end{array}$ \\
\hline Ecuador & V. harveyi & Mass mortalities in P. monodon & $\begin{array}{l}\text { Groumellec et al. } \\
\text { (1995) }\end{array}$ \\
\hline Japan & V. carchariae & $\begin{array}{l}\text { Mass mortalities in Japanese abalone } \\
\text { Haliotis diversicolor }\end{array}$ & $\begin{array}{l}\text { Nishimori et al. } \\
\text { (1998) }\end{array}$ \\
\hline India & V. harveyi & $\begin{array}{l}\text { Tail rot, erythemia, and as white } \\
\text { patches on the body of seahorses, } \\
\text { Hippocampus kuda }\end{array}$ & Raj et al. (2010) \\
\hline India & $\begin{array}{l}\text { V. parahaemolyticus } \\
\text { V. alginolyticus } \\
\text { V. anguillarum } \\
\text { V. vulnificus }\end{array}$ & $\begin{array}{l}\text { Poor growth, lethargic movements, red } \\
\text { discoloration, and mortality in Penaeus } \\
\text { monodon }\end{array}$ & $\begin{array}{l}\text { Thakur et al. } \\
\text { (2003) }\end{array}$ \\
\hline Italy & $\begin{array}{l}V . \text { alginolyticus } \\
V . \text { anguillarum } \\
\text { V. harveyi } \\
\text { V. ordalii } \\
\text { V. salmonicida } \\
\text { V. vulnificus }\end{array}$ & $\begin{array}{l}\text { Mass mortalities in bivalves farm } \\
\text { located in Mar Piccolo in Taranto }\end{array}$ & $\begin{array}{l}\text { Cavallo et al. } \\
(2012)\end{array}$ \\
\hline $\begin{array}{l}\text { West coast of } \\
\text { North America }\end{array}$ & V. tubiashii & $\begin{array}{l}\text { Reduce the bivalve shellfish larval and } \\
\text { seed production. One hatchery in their } \\
\text { study estimated a } 59 \% \text { loss in } 2007 \\
\text { production. }\end{array}$ & $\begin{array}{l}\text { Elston et al. } \\
(2008)\end{array}$ \\
\hline
\end{tabular}


Moreover, recent findings from Costa et al., (2015) stated that Vibrio spp resistant to $\beta$ lactam and tetracycline has been detected in farmed shrimp and cultivation areas. Thus, the emergence of resistant bacteria to antimicrobial drugs may be indicative of the indiscriminate use of these drugs in aquaculture system. Surprisingly, the unresponsible use of antibiotics not only influence the cultivation site but also have the potential impact to develop antibioticresistant bacteria in the environment surrounding the farming operations. Clear evidence from Buschmann et al., (2012) suggests that residues of flumequine, a quinolone with potential cross of resistance with oxolinic acid, were also present at the side that $20 \mathrm{~m}$ and $8 \mathrm{~km}$ distant from the aquaculture facility. The residues were most likely carried by marine currents from the aquaculture sites that already used the antibiotics for more than ten years.

Based on the above information, a holistic approach, which includes environment, host and pathogen, to protect the aquatic animals from vibriosis without using antibiotics are needed to make the industry more sustainable (Defoirdt et al.,2007). This prophylactic approach will become a good complement for the restriction use of antibiotics in aquaculture in many countries (Cabello, 2004; Goldburg and Naylor, 2005). Moreover, in the view of good health management practices, disease prevention is more important than the treatment of diseased animals (Brumley, 1921). Therefore, the application of prophylactic approaches will be more sustainable especially within the aquaculture system that culture the animals in several types of system and not always in their most optimal conditions. Several prophylactic approaches directed towards vibriosis that have been developed and applied in aquaculture system that aim to control and prevent the disease will be briefly discussed throughout the following paragraphs, namely:

Moreover, the oral administration of $\beta$ glucan may be beneficial to enhanced the immune system of European seabass

Similar studies have also been done in invertebrates. A number of reports from Marques (2005) and Soltanian (2007) confirm that daily addition of small amounts of yeast and/or glucan to a poor performing feeds provide protection to Artemia against the pathogenic Vibrio campbellii while for Artemia that do not supplemented with yeast and/or pure glucan cannot survive against pathogenic Vibrio campbellii. Moreover, the oral administration of peptidoglycan (PG) derived immunostimulation, vaccination, probiotics and quorum sensing to inhibit the virulence factors of vibriosis.

\section{Immunostimulation}

The word of 'immunostimulant' refers to any chemical compound that activates white blood cells (Leukocytes) and hence may render the animals more resistant to infection by a harmful micro-organisms in the culture environment, such as: viruses, bacteria, fungi and parasites (Raa, 2000). Moreover, according to Raa (1996), immunostimulants can be grouped into: (i) structural elements of bacteria: lipopolysaccarides, capsular glycoproteinsand muramylpeptides, (ii) Various $\beta-1,3$ glucan from bacteria and mycelial fungi, (iii) $\beta-1,3 / 1,6$-glucans from the cell wall of baker's yeast, (iv) glycans from various biological structures, (v) peptides, (vi) nucleotides and (vii) various synthetic products. The use of immunostimulants will increasethe resistance of aquatic organisms against infectious diseasesby enhancing their adaptive and innate defense mechanisms. The role of immunostimulants for their immunological and pharmacological effects have been discussed in detail, including the efficiency and dose-effect relationship of immunostimulants in shrimps (Sajeevan et al., 2009; Duvic and Söderhäll 1990) and aquatic organisms (Castro et al.,1999). In terms of vibriosis, the application of many commercial immunostimulants have succesfully been used to increase the resistanceagainst vibriosis in fish (Spain-ortuno et al., 2002). Bridle et al. (2005) reported the dietary administration of $\beta$-glucan to Atlantic salmon (Salmon salar) stimulates the respiratory burst activity (RBA) of head kidney macrophage in vitro and challenge tests with infectious pathogen (in vivo experiment) showed negative effect on RBA, serum lysozyme production and diseases resistance to amoebic gill disease. Dicentrarchus labrax against $V$. anguillarum infection (Bonaldo et al., 2007)

from Bifidobacterium thermophilum was able to enhance the phagocytic activity of the granulocytes and increase the resistance of kuruma shrimp $P$. japonicas against virulent strain of Vibrio penaeicida (Itami et al., 1989).However, although various immunostimulant substances have been used and their suitability to increase the immune reactions of animals (Raa 1996, 2000) and their capability to eliminate pathogens (Vici et al., 
2000) has been studied, only a few of them are suitable for aquaculture purposes (Raa et al. 1996; Siwicki et al.,1998).

\section{Vaccination}

The purpose of vaccination is to induce and build resistance in the host organisms against a wide array of pathogenic diseases; and this remains as the most viable approach in the prevention of fish diseases (Caipang et al., 2014). Generally, there are three type of vaccines in fish, include traditional inactivated vaccine (Sommerset et al., 2005), live attenuated and sub unit vaccines (Caipang et al., 2014). The administration for these vaccines in fish can be applied through injection (both intraperitoneal and intramuscular injection), oral, direct immersion or spraying (Yang and Chen, 1996). Injection method remains to be the most popular method of choice in fish vaccination mainly due to the fish received an exact dose of vaccine resulted in the best effect. However, the excessive operation, time-consuming and difficult to administer to fry and other small fishes become the limitation factor of this injection method (Caipang et al., 2014).

There are several components that have been tested as vaccines against infection caused by vibriosis. The outer membrane protein (OMP) of this Gram-negative bacteria has an important role in the interaction between bacteria with host. Mao et al. (2007) stated that the production of recombinant OMP from $V$. harveyi and $V$. parahaemolyticus was able to protect yellow croaker Pseudosciaena crocea from infection with virulent strains of both bacteria. Moreover, DNA vaccine by using the OMP gene against $V$. harveyi have been tested in terms of their protective ability following bacterial challenge in Asian seabass. However, the relative efficiency of these DNA vaccines was considered as moderate level even injected intramuscularly or incorporated with chitosan particles and administered as feed (Kumar et al., 2007, 2008). Other components that have been tested as animals (Balcazar et al., 2006). Probiotics have several benefits for aquaculture, such as production of inhibitory compounds, source of nutrients and enzymatic contribution to digestion and they can also help to improve water quality (Moriarty, 1997; Sahu et al., 2008). The isolation of bacterial and yeast flora as the probiotics from rainbow trout were able to inhibit the growth of $V$. anguillarum in a well diffusion assay (Spanggaard et al., 2001). Furthermore, field vaccine candidate is the haemolysin gene from $V$. harveyi produced in yeast cells. According to Zhu et al. (2006) the yeast cell displaying haemolysin may be more suitably used as the live vaccine in turbot to avoid its infection by $V$. harveyi.

Vaccination receiving most attention and claims for success in promoting survival of fish. However, based on the assumed lack of antigen receptor diversity in invertebrates, the possibility of vaccines application in invertebrates has been a paradigm for those that assume the nonexistence of an adaptive immune response in these animals (Arala-chavez and Sequeira, 2000). Crustacean defense against pathogens have three principle known components: phagocytosis, nodulation and encapsulation (Bang, 1983). However, further study conducted by Arala-chavez and Sequeira (2000) conclude that an adaptive immune response can be detected in invertebrates after challenge with certain antigens but not with others. Thus it seems reasonable to accept the results stated that the application of vaccine was able to significantly reduced mortality in cultured kuruma prawns Penaeus japonicas when they were challenged by Vibrio injection (Itami et al., 1989). Another success story on the application of vaccine in the invertebrates also showed by Kumar et al. (2008) stated that the application of DNA vaccine pVP 28 were able to protect shrimp and significantly induce higher survival compared to the control. Moreover, based on the immunological parameter analysis, the vaccinated shrimp showed significantly higher level of prophenoloxidase and superoxide dismutase (SOD) when compared to the control groups.

\section{Probiotics}

The possibilities for using probiotics as a prophylactic approach have gained much interest in the last years (Skjermo and Vadstein, 1999). Important probiotic strains can be isolated from indigenous and exogenous microbiota of aquatic experiments in penaeid aquaculture ponds have shown that the addition of selected strains of Bacillus to pond water reduces Vibrio harveyicaused mortality (Moriarty, 1998). However, even the use of probiotic bacterial cultures offers an alternative to antibiotic treatment, the regular addition of probiotics bacteria to maintain high concentrationsis the most important limitation because it makes probiotic techniques inefficient and cost-effective (Vine et al., 2006). 


\section{Quorum sensing}

The definition of quorum sensing (QS) as described by Defoirdt et al. (1997) is a mechanism by which bacteria coordinate the expression of certain genes in response to the presence or absence of small signal molecules. In Gram-negative bacteria, such as Vibrio, QS can be generalized into a one or multi-channel system circuits (Wang et al., 2008). In the onechannel system, bacteria use Acylated Homoserine Lactones (AHLs) as the sole signal molecules. According to Miller and Bassler (2001), AHL is synthesized by the Luxl protein and is detected by the LuxR protein. When a certain threshold concentration of signals is achieved, LuxR binds to the auto inducer and activates the transcription of the luxICDABE operon that encodes the genes responsible for luminescence production. High mortalities in different aquaculture organisms are observed when exposed to AHLs. The negative impact of AHLs is probably due to the stimulation of bacterial virulence factors that are controlled by QS.

To date, in order to inhibit the quorum sensing, a non-bacteriostatic/molecules that can restrain the virulence of pathogens through interference with quorum sensing that enabling the host to control the pathogen are being developed (Wang et al., 2008). In terms of vibriosis, Halogenated furanones and natural furanone-4-bromo-5-(bromomethylene)-3-butyl$2(5 \mathrm{H})$-furanone blocks quorum sensing regulated gene expression in Vibrio harveyi by decreasing the DNA-binding activity of the quorum sensing response regulator (Defoirdt et al., 2007). Several findings have reported that numerous aquatic organisms such as micro-algae, macroalgae, invertebrates, or even other bacteria have the potential to disrupt the quorum sensing. The mechanism of action varies from degradation of signals through enzymatic or chemical inactivation to antagonistic as well as agonistic activities (Natrah, 2011). For sustainable aquaculture, the use of natural resources to disrupt the communication offers a promising alternative to control the bacterial infection caused by Vibrio spp.

\section{REFERENCES}

Aguirre-Guzmán, G., H.M. Ruiz, and F. Asxencio. 2004. A review of extracellular virulence product of Vibrio species important in disease of cultivated shrimp. Aquaculture Res 35, 1395-1404.

Akinbowale, O.L., H. Peng, and M.D. Barton. 2006. Antimicrobial resistance in bacteria isolated from aquaculture sources in Australia. Journal of Applied Microbiology 100, 1103-1113.

Aldeman, D.J., and T.S. Hastings. 1998. Antibiotic use in aquaculture: development of antibiotic resistance-potential for consumer health risks. Int. J. Food Sci. Technology 33, 139-155.

Amaro, C, and E.G. Biosca. 1996. Vibrio vulnificus biotype 2 , pathogenic for eels, is also an opportunistic pathogen for humans. Appl. environ. Microbiology 62, 1454-1457.

Amaro, C., E.G. Biosca., B. Fouz., A.E. Toranzo, and E. Garay. 1994. Role of iron, capsule, and toxins in the pathogenicity of Vibrio vulnificus biotype 2 for mice. Infect Immun 62: 759-763

Anderson J.W, and D.A. Conroy. 1970. Vibrio diseases in fishes. In: Snieszko SF (ed.): A Symposium on Diseases of Fishes and Shellfishes. Washington, D.C., American Fisheries Society, Special Publication No. 5, 266-272

Andrews, L.S. 2004. Strategies to control Vibrios in Molluscan Shellfish. Food Protection Trends 24, 70-76.

APEC/FAO/NACA/SEMARNAP. 2000. Report of a Joint APEC/FAO/NACA/SEMARNAP adhoc expert consultation on trans-boundary aquatic animal pathogen transfer and development of harmonized standards on aquaculture health management, 24-28 July 2000, Puerto Vallarta, Jalisco, Mexico.

Arala-Chavez, M, and T. Sequeira. 2000. Is there any kind of adaptive immunity in invertebrates? Aquaculture 191, 247-258

Austin, B., and D.A. Austin. 2007. Bacterial fish pathogens: disease of farmed and wild fish, $4^{\text {th }}$ Ed. Springer Praxis Publishing, Chichester, United Kingdom, 552 pp.

Balcázar, J.L., L. Ruíz-Zarzuela, D. Cunningham, D. Vendrell, and J.L. Múzquiz. 2006. The role of probiotics in aquaculture. Vet. Microbiology 114, 173-186.

Bonaldo, A., K.D. Thompson, A. Manfrin, A. Adams, E. Murano, A.L. Mordenti, and P.P. Gatta. 2007. The influence of dietary $\beta$ glucans on the adaptive and innate immune response of European sebass (Dicentrarchus labrax) vaccinated against vibriosis. Ital. J. Animal Science 6, 151-164. 
Boyd, E.F., B.M. Davis, and B. Hochhut. 2001. Bacteriophage-bacteriophage interactions in the evolution of pathogenic bacteria. Trends Microbiol 9, 137-144.

Bridle, C., R.P. Riemsma., J. Pattenden., A.J. Soeden., I.S. Watt, and A. Walker. 2005. Systematic review of the effectiveness of health behavior interventions based on the transtheoretical model. Psychology and Health, in press.

Brumley, O.V. 1921. A Text-book of the Diseases of the Small Domestic Animals. Lea and Febiger. $672 \mathrm{pp}$.

Buschmann, A.H., A. Tomova, A. Lopez, M.A. Maldonado, L.A. Henriquez, L.Ivanova, F. Moy, H.P. Godfrey, and F.C. Cabello. 2012. Salmon aquaculture and antimicrobial resistance in the marine environment. PLoS ONE 7(8), e42724.

Cabello, F.C. 2004. Antibiotics and aquaculture in Chile: implications for human and animal health. Rev Med Chil 132, 1001-1006.

Caipang, C.M.A., B.L. Jomer, and L-y. M. Clara. 2014. Updates on the vaccination against bacterial diseases in tilapia, Oreochromis spp. and Asian seabass, Lates calcarifer. AACL Bioflux 7, 184-193.

Castro, R., N. Couso, A. Obach, and J. Lamas. 1999. Effect of different $\beta$-glucans on the respiratory burst of turbot (Psetta maxima) and gilthead seabream (Sparus aurata) phagocytes. Fish Shellfish Immunology 9, 529-541.

Cavallo, R.A., M.I. Acquaviva, G.Alabiso, M.Milillo, M.Narracci, and L. Stabili. 2012. Study of aquaculture pathogenic vibrios in the Mar Piccolo of Taranto (Ionian Sea, Italy). Biol Mar Mediterrania 19, 154-155.

Chatterjee, S, and S. Haldar. 2012. Vibrio Related Diseases in Aquaculture and Development of Rapid and Accurate Identification Methods. Marine Science Research and Development 1, 1-7.

Chen, F.R., P.C. Liu, and K.K. Lee. 2000. Lethal attribute of serine protease secreted by Vibrio alginolyticus strains in Kurama Prawn Penaeus japonicus. Zool Naturforsch 55, 94-99.

Costa, R.A., R.L. Araújo., O.V. Souza, and R.H.S.dF. Vieira. 2015. Antibiotic-Resistant Vibrios in Farmed Shrimp. BioMed Research International 1, 1-5

Crosa, J. H., M.H. Schiewe, and S. Falkow. 1977. Evidence for plasmid contribution to the virulence of the fish pathogen Vibrio anguillarum. Infection and Immunity 18, 509-513.

Dalsgaard, A. 1998. The occurrence of human pathogenic Vibrio spp. and Salmonella in aquaculture. International Journal of Food Science and Technology 33, 127-138.

Defoirdt. T., N. Boon, P. Sorgeloos, W. Verstraete, and P. Bossier. 2007. Alternatives to antibiotics to control bacterial infections: luminescent vibriosis in aquaculture as an example. Trends in Biotechnology 25 (10), 472-479.

Donnenberg, M.S. 2000.Pathogenic strategies of enteric bacteria. Nature 406, 768-774.

Duvic B, and K. Söderhäll. 1990. Purification and characterization of a B-1,3-glucan binding protein from plasma of the crayfish Pacifastacus leniusculus. J. Biol. Chem., 265, 9327-9332

Egidius, E. 1987. Vibriosis: Pathogenicity and pathology. A review. Aquaculture 67, 15-28.

Elston, R.A., H. Hasegawa, K.L. Humphrey, I.K. Polyak, and C.C. Hase. 2008. Reemergence of Vibrio tubiashii in bivalve shellfish aquaculture: severity, environmental drivers, geographic extent and management. Dis Aquat Organ 82, 119-134.

FAO. 2014. The state of world fisheries and aquaculture: opportunities and challenges. FAO Fisheries and Aquaculture Department.Food and Agriculture Organization of the United Nations. Rome.

Finlay, B.B, and S. Falkow. 1997. Common themes in microbial pathogenicity revisited. Microbiol Mol Biol Rev 61, 136-169

Flegel, T.W. 2012. Historic emergence, impact and current status of shrimp pathogens in Asia. J. Invertebr. Pathol 110, 166-173

Fuller, R. 1989. A review: probiotics in man and animals. Journal of Applied Bacteriology 66, 365-378.

Ghittino, P. and S. Andruetto. 1977. Fish vibriosis in fresh and salt waters of Italy. Bulletin de l'office International des Epizooties 87, 483485.

Goldburg, R, and R. Naylor. 2005. Future seascapes, fishing, and fish farming. Front Ecol Environment 3, 21-28.

Groumellec, M.L.E., P. Haffner, B. Martin, and C. Martin. 1995. Comparative study of bacterial infections responsible for mass mortality in penaeid shrimp hatcheries of the pacific zone. In: Diseases in Asian Aquaculture II. M. Shariff, J.R Arthur and R.P Subasinghe (eds.), p. 163-173. Fish 
Health Section, Asian Fisheries Society, Manila.

Han, J.E., K.F.J. tang, L.H. Tran, and D.V. Lightner. 2015. Photorhabdus insect-related (Pir) toxin-like genes in a plasmid of Vibrio parahaemolyticus, the causative agent of acute hepatopancreatic necrosis disease (AHPND) of shrimp. Diseases of Aqua Org $113,33-40$

Hara-Kudo, Y., K. Sugiyama, T. Nishina, A.Saitoh, H. Nakagawa, T. Ichihara, H.Konuma, J. Hasegawa, and S. Kumagai. 2001. Detection of TDH-producing Vibrio parahaemolyticus $03: \mathrm{K} 6$ from naturally contaminated shellfish using an immunomagnetic separation method and chromogenic agar medium. Kansenshogaku Zasshi 75(11), 955-960.

Harbell, S.O., H.O. Hodgins, and M.H. Schiewe. 1979. Studies on the pathology of vibriosis in coho salmon. Journal of Fish Diseases 2, 527-535.

IDE-JETRO. 2014. Meeting Standards, Winning Markets: Regional Trade Standards Compliance Report East Asia 2013. United Nations Industrial Development Organization (UNIDO); [cited 2015 October 14].

Ishimaru, K., M. Agawa-Matsushita, and K. Muroga. 1996. Vibrio ichthyoenteri sp. Nov., a pathogen of Japanese flounder (Paralichthys olivaceus). International Journal of Systematic Bacteriology 46, 155159.

Isnansetyo, A., Istiqomah, I., Muhtadi, S. Sinansari., R.K. Hernawan., Triyanto, and J. Widada. 2009. A potential bacterial biocontrol agent, strain S2V2 against pathogenic marine Vibrio in aquaculture. World J Microbiol Biotechnol 25, 1103-1113

Itami, T., Y. Takahashi, and Y. Nakamura. 1989. Efficacy of vaccination against Vibriosis in cultured kuruma prawns Penaeus japonicas. Journal of Aquatic Animal Health 1, 238-242.

Itami,T., Y. Takahashi, E.Tsuchihira, H.Igusa, and M. Kondo. 1994. Enhancement of disease resistance of kuruma prawn Panaeus japonicusand increase in phagocytic activity of prawn haemocytes after oral administration of $\beta$-1,3- glucan (Schizophyllan). In: Chou LM, Munro AD, Lam JJ, Chen TW, Cheong LKK, Ding JK, Hooi KK, Khoo DW, Phang VPE, Shim KF, Tan $\mathrm{CH}$ (eds), The Third Asian Fisheries
Forum, Asian Fisheries Society, Manila, pp. 375-368.

Janda, J.M., C. Powers, R.G. Bryant, and S.L Abbott. 1988. Current perspectives on the epidemiology and pathogenesis of clinically significant Vibrio spp. Clinical Microbiology Reviews 1, 245-267.

Kesarcodi-Watson, A., H. Kaspar., M.J. Lategan, and L. Gibson. 2009. Two pathogens of Greenshell $^{\mathrm{TM}}$ mussel larvae, Perna canaliculus: Vibrio splendidus and $a$ coralliilyticus/neptunius-like isolate. Journal of Fish Diseases 32, 499-507

Khouadja, S., F. Lamari, and A. Bakhrouf. 2013. Characterization of Vibrio parahaemolyticus isolated from farmed sea bass (Dicentrarchus labrax) during disease outbreaks. International Aquatic Research 5(13), $1-11$.

Kothary, M.H, and A.S. Kreger. 1987. Purification and characterization of an elastolytic protease of Vibrio vulnificus. J Gen Microbiol 133, 1783-1791.

Kumar, S.R., V. Parameswaran, V.P.I. Ahmed, S.S. Musthaq, and A.S.S Hameed. 2007. Protective efficiency of DNA vaccination in Asian seabass (Lates calcarifer) against Vibrio anguillarum. Fish Shellfish Immunology 23, 316-326

Kumar, S.R., V.P. I. Ahmed, V. Parameswaran, R. Sudhakaran, V.S. Babu, and A.S.S. Hameed. 2008. Potential use of chitosan nanoparticles for oral delivery of DNA vaccine in Asian seabass (Lates calcarifer) to protect from Vibrio (Listonella) anguillarum. Fish Shellfish Immunology 25, 47-56.

Larsen, M.H., N. Balckburn, J.L. Larsen, and J.E. Olsen. 2004. Influences of temperature, salinity and starvation on the motility and chemotactic response of Vibrio anguillarum. Microbiology 150, 1283-1290.

Le Roux, F., K.M. Wegner, C. Baker-Austin, L. Vezzulli, C.R Osorio, C. Amaro, C. et al. 2015. The emergence of Vibrio pathogens in Europe: ecology, evolution, and pathogenesis (Paris, 11-12th March 2015). Front. Microbiol.6, 830.

Lightner, D.V. 1996. A handbook of shrimp pathology and diagnostic procedures for diseases of cultured penaeid shrimp. World Aquacult Soc, Baton Rouge, LA, USA.

Mahnken, C.V.W. 1975. Status report on commercial salmon culture in Puget Sound. Commercial Fish farmer. Aquaculture news 2, 8-11 
Mao, Z., L. Yu, Z. You, Y. Wei, and Y. Liu. 2007. Cloning, expression and immunogenicity analysis of five outer membrane proteins of Vibrio parahaemolyticus j2003. Fish Shellfish Immunology 23, 567-575

Marques, A. 2005. A gnotobiotic Artemia test system to study host microbial interactions. $\mathrm{PhD}$ thesis, Ghent University, Belgium.

Meyer, F.P. 1991. Aquaculture disease and health management. J Anim Sci 69, 42014208.

Miller, M.B, and B.L. Bassler. 2001. Quorum sensing in bacteria. Annu Rev Microbiol 55, 165-199.

Moriarty, J.W.D. 1997. The role of microorganisms in aquaculture ponds. Aquaculture 151, 333-349

Moriarty, J.W.D. 1998. Control of luminous Vibrio species in penaeid aquaculture ponds. Aquaculture 164, 351-358

Muroga, K. 1975. Studies on Vibrio anguillarum and $V$. anguillicida infections. Journal of the Faculty of Fisheries and Animal Husbandry. Hiroshima University 14, 101-205.

Natrah, F.M.I. 2011. Role of bacterial quorum sensing and micro-algae in fish and crustacean larviculture. PhD thesis, Ghent University, Ghent, Belgium.

Nishimori, E., O. Hasegawa, T. Numata, and H. Wakabayashi. 1998. Vibrio carchariae causes mortalities in Japanese abalone Sulculus deversicolor supratexta. Fish pathology 33, $495-502$.

Pasharawipas, T., S. Thaikua, S. Sriurairatana, L. Ruangpan, S. Direkbusarakum, J. Manopvisetcharean, and T.W. Flegel. 2005. Partial characterization of a novel bacteriophage of Vibrio harveyi isolated from shrimp culture ponds in Thailand. Virus Res 114, 63-69.

Prayitno, S. and J. Latchford. 1995. Experimental infections of crustaceans with luminous bacteria related to photobacterium and Vibrio: Effect of salinity and $\mathrm{pH}$ on infectiosity. Aquaculture 132, 105-112.

Pridgeon, J.W. and P.H. Klesius. 2012. Major bacterial diseases in aquaculture and their vaccine development. CAB Reviews 7, 1 16.

Raa, J. 2000. The use of immunestimulants in fish and shellfish feeds. In: Cruz - Suárez, L.E., D. Ricque-Marie, M. Tapia-Salazar, M.A. Olvera-Novoa, and R. CiveraCerecedo.(Eds.). Avances en Nutrición Acuícola V. Memorias del V Simposium
Internacional de Nutrición Acuícola. 19-22 Noviembre, 2000. Mérida, Yucatán, Mexico.

Raa, J. 1996. The Use of Immunostimulatory Substances in Fish and Shellfish Farming. Reviews in Fisheries Science 4 (3), 229288.

Raj, S.T., A.P. Lipton, and G.S. Chauhan. 2010. Characterization and infectivity evaluation of Vibrio harveyi causing white patch disease among captive reared seahorses, Hippocampus kuda. Indian Journal of Marine Sciences 39(1), 151-156.

Rhodes, J.B., D. Schweltzer, and J.E. Ogg. 1985. Isolation of non-01 Vibrio chloreae associated with enteric disease of herbivores in western Colorado. J. Clin. Microbiol 22: 572-575.

Rucker, R. R., B.J Earp, and E.J. Ordal. 1954. Infectious diseases of Pacific salmon. Trans. Am. Fish. Soc. 83. 297-312

Ruwandeepika, H.A.D. 2010.Expression of virulence genes of Vibrios belonging to the harveyi clade in the brine shrimp Artemia. PhD thesis, Ghent University, Belgium. ISBN 978-90-5989-409-9

Saad, T.T, and S.T. Atallah. 2014. Studies on bacterial infection in marine fish. Journal of Arabian Aquaculture Society 9 (1), 1-20

Sahu, M.K., N.S. Swarnakumar, K. Sivakumar, T. Thangaradjou, and L. Kannan. 2008. Probiotics in aquaculture: importance and future perspectives. Indian J. Microbiology 48,299-308.

Sajeevan, T.P., R. Philip., I.S.B. Singh. 2009. Dose/frequency: A critical factor in the administration of glucan as immunostimulant to Indian white shrimp $(P$. monodon) Fenneropenaeus indicus. Aquaculture 287, 248-252.

Siwicki, A.K., M. Morand, P. Klein, M. Studnicka, and E. Terech-Majewska. 1998. Modulation of nonspecific defence mechanisms and protection against diseases in fish. Acta Vet Brno 67, 323-328.

Skjermo, J, and O. Vadstein. 1999. Techniques for microbial control in the intensive rearing of marine larvae. Aquaculture 177, 333-343.

Smibert, R.M, and Krieg, N.R. 1994. Phenotypic characterization. In: Gerhardt P, Murray RGE, Wood WA, Krieg NR (eds) Methods for general, molecular bacteriology. American Society for Microbiology, Washington, pp 607-654

Soltanian, S. 2007. Protection of gnotobiotik Artemia against Vibrio campbelli using 
baker's yeast strains and extracts. $\mathrm{PhD}$ thesis. Ghent University. Belgium.

Sommerset, I., R. Skern, E. Biering, H. Bleie, I.U. Fiksdal, S. Grove, and A.H. Nerland. 2005. Protection against Atlantic halibut nodavirus in turbot is induced by recombinant capsid protein vaccination but not following DNA vaccination. Fish Shellfish Immunology 18, 13-29

Soto-Rodriguez, S.A., B. Gomez-Gil, R. LozanoOlvera, M. Betancourt-Lozano, M.S. Morales-Covarrubias. 2015. Field and experimental evidence of Vibrio parahaemolyticus as the causative agent of acute hepatopancreatic necrosis disease of cultured shrimp (Litopenaeus vannamei) in northwestern Mexico. Appl. Environ. Microbiology 81, 1689 - 1699.

Spain-Ortuno, J., A. Cuesta, A. Rodriguez, M.A. Esteban, and J. Meseguer. 2002. Oral administration of yeast, Saccharomyces cerevisiae, enhances the cellular innate immune response of gilthead seabream (Sparus aurata L.). Vet. Immunol. Immunop. 85, 41-50.

Spanggaard, B., I. Huber, J. Nielsen, T. Nielsen, and L. Gram. 2000. Proliferation and location of Vibrio anguillarum during infection of rainbow trout, Oncorhynchus mykiss. Journal of Fish Diseases 23, 423427.

Thakur, A.B., R.B. Vaidya, and S.A. Suryawanshi. 2003. Pathogenicity and antibiotic susceptibility of Vibrio species isolated from moribund shrimps. Indian Journal of Marine Sciences 32(1), 71-75

Thompson, F.L., T. Lida, and J. Swings. 2004. Biodiversity of vibrios. Microbiol. Mol. Biol. Rev. 68, 403-431

Trust, T.J., I.D. Cortice., A.G. Khouri, J.H. Crosa, and M.H. Schiewe. 1981. Serum resistance and hemagglutination abiiity of marine vibrios pathogenic for fish. Infect. Immun., 34, $702-707$.

Vandenberghe, J., F.L. Thompson, B. GomezGill, and J. Swings. 2003. Phenotypic diversity amongst Vibrio isolates from marine aquaculture systems. Aquaculture 219, 9-20

Vanmaele, S., T. Defoirdt, I. Cleenwerck, P. De Vos, and P. Bossier. 2015. Characterization of the virulence of Harveyi clade vibrios isolated from a shrimp hatchery in vitro and in vivo, in a brine shrimp (Artemia franciscana) model system. Aquaculture 435, 28-32

Venkateswaran, K., N. Dohmoto, and S. Harayama. 1998. Cloning and nucleotide sequence of the gyrB gene of Vibrio parahaemolyticus and its application in detection of this pathogen in shrimp. Applied and Environmental Microbiology 64, 681-687.

Vezzulli, L., I. Brettar, E. Pezzati, P.C. Reid, R.R. Colwell, M. GHöfle, et al. 2012. Long-term effects of ocean warming on the prokaryotic community: evidence from the vibrios. ISME J. 6, 21-30.

Vici, V., I.S. Bright Singh, and S.G. Bhat. 2000. Application of bacterins and yeast Acremonium dyosporii to protect the larvae of Macrobrachium rosenbergii from vibriosis. Fish Shellfish Immunology 1, 559563.

Vine, N.G., W.D. Leukes, and H. Kaiser. 2006. Probiotics in marine larviculture. FEMS Microbiol Rev 30, 404-427.

Wang L.H., Y.H. Dong, and L.H Zhang. 2008. Quorum quenching: impact and mechanisms. In: Winans SC, Bassler BL. Chemical communication among bacteria. ASM, Washington, pp 379-392.

Wei, Q. 2002. Social and economic impacts of aquatic animal health problems in aquaculture in China. In: Arthur JR, Phillips $M J$, Subasinghe RP, Reantaso $M B$, and MacRae IH. (Eds.). Primary Aquatic Animal Health Care in Rural, Small-Scale, Aquaculture Development. FAO Fish Technical Paper No. 406. FAO. p. 55 - 61

Woo, P.T.K, and D.W. Bruno. (Ed.). 2011. Fish diseases and disorders: 3 . Viral, bacterial and fungal infections. 2nd. Edition. $C A B$ International: Oxford shire. ISBN 978-184593-554-2.ix, $930 \mathrm{pp}$

Yang, X.L, and Y.X. Chen. 1996. The existing situation and tendency in development of fish vaccine. J Fish China 20, 159-167

Zhu, K., Z. Chi, J. Li, F. Zhang, M. Li, H.N. Yasoda, and L. Wu. 2006. The surface display of haemolysin from Vibrio harveyi on yeast cells and their potential applications as live vaccine in marine fish. Vaccine 24 , $6046-6052$.

Zorriehzahra, M.J, and Banaederakhshan, R. 2015. Early Mortality Syndrome (EMS) as new Emerging Threat in Shrimp Industry. Adv. Anim. Vet. Sci. 3(2s), 64-72. 